\title{
ANALISIS HASIL BELAJAR BIOSTATISTIKA BERDASARKAN METODE PEMBELAJARAN LURING DAN DARING
}

\author{
Studi Komparatif Nilai Akhir Semester Mata Kuliah Biostatistika Sebelum dan \\ Saat Pandemi COVID-19 di Perguruan Tinggi Swasta di Sulawesi Utara
}

(ANALYSIS OF BIOSTATISTICS LEARNING OUTCOMES BASED ON OFFLINE AND ONLINE LEARNING METHODS)

\author{
I Gede Purnawinadi \\ Fakultas Keperawatan Universitas Klabat
}

Jl. Arnold Mononutu, Airmadidi Bawah, Minahasa Utara-Sulawesi Utara

E-mail: purnawinadi87@unklab.ac.id

\begin{abstract}
Abstrak
Situasi pandemi COVID-19 saat ini tidak hanya mempengaruhi kondisi kesehatan global namun dampak yang sangat signifikan juga terjadi dalam dunia pendidikan. Proses pembelajaran yang konvensional secara luring beralih menjadi daring akibat kondisi yang tidak memungkinkan untuk dilaksanakan proses belajar mengajar tatap muka secara langsung yang tentunya mempengaruhi hasil belajar peserta didik. Penelitian ini bertujuan menganalisis hasil belajar mata kuliah biostatistika melalui uji komparatif nilai akhir semester sebelum dan saat pandemi di salah satu perguruan tinggi swasta di Sulawesi Utara. Data nilai akhir dari 228 mahasiswa semester genap tahun ajaran 2018-2019 dan 2019-2020 dikumpulkan dengan akses melalui akun peneliti di sistem informasi perguruan tinggi swasta sebagai tempat penelitian ini dilaksanakan kemudian data disimpan dalam bentuk excel. Data dianalisis melalui uji statistika non parametris MannWhitney U-test melalui aplikasi SPSS yang sudah terinstall pada komputer. Hasil penelitian menunjukkan secara deskriptif bahwa median nilai akhir semester mata kuliah biostatistika mahasiswa dengan metode pembelajaran luring maupun daring adalah sama yaitu $84 \%$, bahkan analisis bivariat didapati nilai $p=0,445$ $>0,05$ yang berarti pada alpha $5 \%$ tidak ada perbedaan bermakna antara nilai akhir semester mahasiswa dengan metode luring maupun daring. Kemajuan teknologi dan konsep merdeka belajar memungkinkan para mahasiswa lebih aktif dan lebih bebas belajar mandiri melalui metode daring sehingga proses belajar dimasa pandemi tidak berdampak buruk terhadap hasil belajar dibandingkan dengan kondisi belajar melalui metode luring sebelum pandemi.
\end{abstract}

Kata kunci: hasil belajar, luring, daring, metode pembelajaran, pandemi COVID-19

\begin{abstract}
The current COVID-19 pandemic situation not only affects global health conditions but a very significant impact also occurs in the world of education. The conventional offline learning process switches to online due to conditions that do not allow face-to-face teaching and learning processes to be carried out directly which of course affects the learning outcomes of students. This study aims to analyze the learning outcomes of the biostatistics subject through a comparative test of final semester scores before and during the pandemic at a private university in North Sulawesi. Final grade data from 228 even semester students for the 2018-2019 and 2019-2020 academic years were collected with access through the researcher's account in the information system of private tertiary institutions where this research was carried out then the data was stored in excel form. Data were analyzed through non-parametric statistical Mann-Whitney U-test through the SPSS application that was installed on the computer. The results showed descriptively that the median final score of the semester in the biostatistics course of students with offline and online learning methods was the same, namely 84\%, even the bivariate analysis found that the value of $p=0.445>0.05$, which means that at 5\% alpha there was no difference between values. the end of the student semester using offline and online methods. Advances in technology and the concept of independent learning allow students to be more active and freer to learn independently through online methods so that the learning process during the pandemic does not have a negative impact on learning outcomes compared to learning conditions through the offline method before the pandemic.
\end{abstract}

Keywords: learning outcomes, offline, online, lerning method, the COVID-19 pandemic 


\section{PENDAHULUAN}

Masa pandemi COVID-19 saat ini menyebabkan dunia pendidikan memasuki fase dalam penyesuaian proses pembelajaran yang biasanya dilakukan secara luring (luar jaringan) yaitu tatap muka langsung di ruang kelas, menjadi pembelajaran daring (dalam jaringan) yang dikenal dengan metode jarak jauh melalui memanfaatkan teknologi sebagai sarana penunjang pembelajaran di perguruan tinggi (Wijayanti, Yunita, \& Dharmanto, 2020). Luthra \& Mackenzi (2020) menyebut bahwa kondisi pandemi COVID-19 saat ini mengubah cara mendidik generasi masa depan, proses pendidikan di seluruh dunia saling terhubung dan memberi peluang lebih luas teknologi berperan dalam menunjang pendidikan. Selain itu, Tam dan El Azar (2020) menyatakan pandemi menyebabkan perubahan mendasar dalam pendidikan global selain mengubah cara mendididik, kesenjangan digital menyebabkan pergeseran baru dalam pendekatan pendidikan.

Data UNESCO (2020) menyebut 1,5 miliar peserta didik dan 63 pendidik di 191 negara yang terdampak pandemi Covid-19, sesuatu yang tidak pernah terjadi sebelumnya. UNICEF, WHO dan IFRC dalam COVID-19 Prevention and Control in Schools (2020) menyebut bahwa ketika situasi persebaran virus semakin cepat proses pendidikan harus tetap berjalan melalui kegiatan pembelajaran online dengan menggunakan berbagai media. Perkuliahan daring menjadi sarana utama dalam pembelajaran saat ini, penggunaan media aplikasi online, seperti grup whatsapp, grup telegram, google classroom, dan media aplikasi lain (Widiyono, 2020).

Fakta menunjukkan betapa COVID-19 telah membuat percepatan transformasi pendidikan dalam waktu yang sangat singkat, seluruh dunia mengubah pola pembelajaran konvensional berbasis tatap muka menjadi pembelajaran jarak jauh yang sangat mengandalkan teknologi. Dunia pendidikan kemudian harus putar haluan untuk mengubah pembelajaran berbasis tatap muka menjadi pembelajaran daring. Transformasi digital ini adalah cara yang sangat aman untuk memutus penularan virus corona, karena hak para mahasiswa dalam mendapatkan pendidikan tetap menjadi prioritas dan protokol kesehatan tidak terabaikan.

Pembelajaran daring di Indonesia diatur melalui Surat Edaran Kemdikbud No 4 Tahun 2020 mengenai Pelaksanaan Pendidikan Dalam Masa Darurat Coronavirus Disease (Covid-19). Terdapat tiga poin kebijakan yang berkaitan dengan pembelajaran daring. Pertama mengenai pembelajaran daring untuk memberi pengalaman belajar yang bermakna, tanpa terbebani tuntutan menuntaskan seluruh capaian kurikulum untuk kelulusan. Kedua yaitu dapat difokuskan pada pendidikan kecakapan hidup, antara lain mengenai pandemi COVID-19. Ketiga, aktivitas dan tugas pembelajaran dapat bervariasi antar peserta didik, sesuai minat dan kondisi masing-masing, termasuk mempertimbangkan kesenjangan akses/fasilitas belajar di rumah.

Biostatistika merupakan ilmu terapan statistik yang dipergunakan bagi penelitian-penelitian ilmu kesehatan dalam mencapai tujuan penelitian yang diarahkan melalui uji empirik dengan desain penelitian yang terstruktur dengan baik (Susilo, Aima, dan Suprapti, 2014). Melalui pemahaman biostatitika diharapkan dapat memperluas wacana konfirmasi ilmu dan teori. Pemikiran tentang belajar ilmu statistik sangat sulit tentunya mempengaruhi proses belajar dalam mata kuliah biostatistika dengan berbagai keterbatasan dalam situasi pandemi saat ini, sehingga memerlukan faktor-faktor pendukung dalam mencapai target pembelajaran yang lebih baik. Penelitian ini bertujuan menganalisis perbedaan hasil belajar biostatitika sebelum dan saat pandemi COVID-19 sehingga dapat digunakan sebagai bahan pertimbangan bagi institusi pendidikan terkait dalam melakukan upaya proses pembelajaran yang lebih baik.

\section{METODE}

Penelitian ini merupakan jenis kuantitaif bersifat survei analitik melalui pendekatan cross sectional, merupakan jenis penelitian yang menekankan waktu pengumpulan, pengukuran, observasi data variabel hanya satu kali pada satu saat (Nursalam, 2008). Data penelitian ini merupakan hasil belajar mata kuliah biostatistika berupa nilai akhir semester mahasiswa 
keperawatan sebelum dan saat pandemi di salah satu perguruan tinggi swasta di Sulawesi Utara. Data nilai akhir dari 228 mahasiswa semester genap tahun ajaran 2018-2019 dan 2019-2020 dikumpulkan dengan teknik total sampling, akses melalui akun peneliti di sistem informasi perguruan tinggi swasta sebagai tempat penelitian ini dilaksanakan kemudian data disimpan dalam bentuk excel. Tahap awal analisis data menunjukkan distribusi data variabel tidak normal, sehingga analisis lanjut menggunakan uji komparatif non parametris Mann-Whitney U-test melalui aplikasi SPSS yang sudah terinstall pada komputer.

Penelitian ini dilaksanakan setelah mendapatkan ijin resmi dari pihak institusi terkait. Pelaksanaan penelitian ini menerapkan prinsip etika autonomy yaitu tanpa unsur pemaksaan dengan bersikap adil (justice) yaitu semua data hasil belajar mahasiswa yang kontrak mata kuliah biostatistika tanpa diskriminasi pada data hasil belajar mahasiswa tertentu. Penelitian ini tentunya bertujuan baik dalam upaya menelaah komparasi hasil belajar sebelum dan saat pandemi berlangsung, sehingga prinsip beneficience nyata dalam penelitian ini. Pelaksanaan penelitian ini sedapat mungkin peneliti menghindari hal-hal yang merugikan, sehingga prinsip non-maleficience dapat diterapkan, begitu pula confidentiality sangat dijunjung sebagai suatu kerahasiaan dan melindungi data informasi hanya untuk kepentingan penelitian.

\section{HASIL DAN PEMBAHASAN}

Hasil analisis awal uji normalitas data ditampilkan pada tabel 1 berikut ini:

Tabel 42. Uji normalitas data variabel

\begin{tabular}{crccc|ccc}
\hline & \multicolumn{3}{c}{ Kolmogorov-Smirnov } & \multicolumn{3}{c}{ Shapiro-Wilk } \\
\cline { 2 - 8 } & Statistic & $d f$ & Sig. & Statistic & $d f$ & Sig. \\
\hline nilai_akhir_semester &, 085 & 228 &, 000 &, 972 & 228 &, 000 \\
\hline
\end{tabular}

Sumber: data primer output analisis SPSS

Analisis awal ini sebagai uji kelayakan untuk analisis statistik parametik bila asumsi distribusi data normal terpenuhi. Distribusi data variabel sesuai dengan hasil analisis uji normalitas yang ditunjukkan pada tabel 1 . melalui uji Kolmogorov-Smirnov untuk data $n>50$ adalah $0,000<0,05$ yang berarti data nilai hasil belajar biostatitika mahasiswa baik sebelum maupun saat pandemi tidak berdistribusi dengan normal sehingga analisis lanjut bivariat menggunakan statistik non parametik karena asumsi dasar tidak terpenuhi.

Hasil penelitian ini juga menunjukkan deskripsi secara univariat data variabel penelitianyang ditampilkan pada tabel 2 . berikut ini:

Tabel 2. Deskrisi data hasil belajar biostatitika mahasiswa secara univariat

\begin{tabular}{lrrrrrrr}
\hline Hasil Belajar & $\mathrm{N}$ & \multicolumn{1}{c}{ Mean } & Std. Deviation & Median & Minimum & Maximum & Variance \\
\hline Luring & 109 & 83,54 & 5,089 & 84,00 & 70 & 96 & 25,899 \\
Daring & 119 & 83,63 & 6,069 & 84,00 & 70 & 96 & 36,828 \\
Total & 228 & 83,59 & 5,610 & 84,00 & 70 & 96 & 31,468 \\
\hline
\end{tabular}

Sumber: data primer output analisis SPSS

Tabel 2. secara deskriptif menunjukkan bahwa nilai rerata hasil belajar biostatistika dari 228 mahasiswa didapati sebelum pandemi COVID-19 adalah 83,54\% (standar deviasi 5,089), hanya berbeda sedikit dibandingkan dengan saat pendemi yaitu 83,63\% (standar deviasi 6.069). Nilai median, minimum, maksimum hasil belajar mahasiswa dengan metode pembelajaran luring maupun daring adalah sama, beturut-turut yaitu $84 \%, 70 \%$, dan $96 \%$. Nilai varians hasil belajar sebelum pandemi yaitu $25,89 \%$ dan saat pandemi $36,82 \%$, yang berarti hasil belajar dengan metode daring lebih bervariasi dibandingan hasil belajar dengan metode luring. Untuk analisis lebih mendalam dapat dilihat pada analisis bivariat selanjutnya.

Tabel 3. Analisis komparatif hasil belajar biostatistika sebelum dan saat pandemi COVID-19 


\begin{tabular}{lr}
\hline & nilai_akhir_semester \\
\hline Mann-Whitney U & 6106,000 \\
Wilcoxon W & 12101,000 \\
Z &,- 764 \\
Asymp. Sig. (2-tailed) &, 445 \\
\hline
\end{tabular}

Sumber: data primer output analisis SPSS

Komparasi hasil belajar melalui analisis bivariat yang ditunjukkan pada tabel 3. dengan $p$ value $0,445>0,005$ yang berarti pada alpha $5 \%$ tidak terdapat perbedaan yang bermakna antara nilai akhir semester mahasiswa yang belajar biostatistika sebelum maupun saat pandemi COVID-19.

Pandemi Covid-19 menuntut sektor pendidikan untuk berbenah melakukan berbagai inovasi dan adaptasi demi keberlangsungan proses pembelajaran. Instruksi presiden dan Surat Edaran Menteri Pendidikan dan Kebudayaan terkait belajar dari rumah ditindaklanjuti oleh kampus dengan melaksanakan pembelajaran dari rumah baik secara sinkronis maupun asinkronis (Rustandi, 2020). Kondisi pembelajaran yang terbatas secara daring antara dosen dan mahasiswa, diatasi pihak kampus dengan mempersiapkan diri menyusun kebijakan dan langkah strategis agar proses aktivitas kegiatan berbagi materi topik kuliah tetap berjalan menggunakan fasilitas aplikasi elearning (Wijayanti, Yunita, \& Dharmanto, 2020).

Pendidikan perguruan tinggi era 4.0 merupakan gagasan transformasi sistem pendidikan tinggi menuju digitalisasi yang mendorong desain kebijakan pengembangan disiplin ilmu dan program studi menuju Cyber University yang dapat menawarkan model pembelajaran daring dengan dukungan sumber daya dosen yang profesional. Pandemi Covid-19 telah menjadi koreksi penting yang menunjukkan kelemahan utama gagasan besar sistem digitalisasi kampus dan sistem pembelajaran daring terkait sarana sistem jaringan telekomunikasi Indonesia yang belum merata. Meskipun demikian, terdapat dinamika positif selama pandemi yakni terciptanya ruang akademik virtual bagi dosen dan mahasiswa serta terjadi peningkatan literasi digital yang memungkinkan para peserta didik lebih leluasa melakukan eksplor belajar (Karim, 2020).

\section{KESIMPULAN}

Berdasarkan hasil penelitian ini, dapat disimpulkan bahwa tidak terdapat perbedaan yang signifikan antara hasil belajar biostatistika dengan metode luring maupun daring. Kemajuan teknologi dan konsep merdeka belajar melalui metode pembelajaran daring memungkinkan para mahasiswa lebih aktif dan lebih bebas belajar mandiri melalui media online sehingga proses belajar dimasa pandemi tidak berdampak buruk terhadap hasil belajar dibandingkan dengan kondisi belajar melalui metode luring atau tatap muka langsung sebelum pandemi. Tentunya proses pembelajaran daring ini harus didukung dengan fasilitas terkait yang memadai dan sumber daya dosen yang tidak kalah penting dalam melaksanakan pembelajaran tersebut.

\section{DAFTAR PUSTAKA}

Karim, B. A. (2020). Pendidikan Perguruan Tinggi Era 4.0 Dalam Pandemi Covid-19 (Refleksi Sosiologis).

Education and Learning Journal Vol 1, No 2. http://jurnal.fai.umi.ac.id/index.php/eljour/article/view/54 DOI: http://dx.doi.org/10.33096/eljour.v1i2.54

Kementerian Pendidikan dan Kebudayaan. Surat Edaran Kemdikbud No 4 Tahun 2020 mengenai Pelaksanaan Pendidikan Dalam Masa Darurat Coronavirus Disease (Covid-19). Jakarta: Kemendikbud. Sumber:https://www.kemdikbud.go.id/main/blog/2020/03/mendikbud-terbitkan-se-tentang pelaksanaan-pendidikan-dalam-masa-darurat-covid19.

Luthra, P. \& Mackenzie, S. (2020). 4 Ways Covid-19 Education Future Generations. Sumber: 
https://www.weforum.org/agenda/2020/03/4-ways-covid-19-education-future-generations/.

Nursalam. (2008). Konsep dan Penerapan Metodologi Penelitian Ilmu Keperawatan. (Edisi 2) Jakarta : Info Medika.

Rustandi, D. (2020). Hikmah Pandemi, Kampus Cepat Adaptif dalam Penggunaan Teknologi dan Metode Pembelajaran http://www.dikti.kemdikbud.go.id/kabar/hikmah-pandemi-kampus-cepat-adaptifalam-penggunaan-teknologi-dan-metode-pembelajaran/

Susilo, W. H., Aima, H., Suprapti, F. (2014). Biostatistika Lanjut dan Aplikasi Riset. Jakarta: Trans Info Media

Tam, G. \& El-Azar, D. (2020). 3 Ways The Coronavirus Pandemic Could Reshape Education. Sumber: https://www.weforum.org/agenda/2020/03/3-ways-coronavirus-is-reshaping-education-and-what changes-might-be-here-to-stay/.

UNICEF, IRC, \& WHO. 2020. Key Messages and Actions for COVID-19 Prevention and Control in Schools. Sumber: https://www.who.int/docs/default-source/coronaviruse/key-messages-and-actions-for covid-19-prevention-and-control-in-schools-march-2020.pdf?sfvrsn=baf81d52_4

Widiyono, A. (2020). Efektifitas Perkuliahan Daring (Online) pada Mahasiswa PGSD di Saat Pandemi Covid 19. Jurnal Pendidikan Vol 8 No 2. https://unimuda.e-journal.id/jurnalpendidikan/article/view/458 DOI: https://doi.org/10.36232/pendidikan.v8i2.458

Wijayanti, M., Yunita, T., \& Dharmanto, A. (2020). Pembelajaran Perguruan Tinggi Dalam Jaringan (Daring) Masa Pandemi Covid-19. Jurnal Kajian Ilmiah, 1(1), 31 - 38. https://doi.org/10.31599/jki.v1i1.268 http://ejurnal.ubharajaya.ac.id/index.php/JKI/article/view/268 